\title{
MEWUJUDKAN PELAYANAN UMUM YANG RESPONSIF
}

\section{BERDASARKAN HUKUM RESPONSIF}

\author{
Oleh
}

L. Tri Setyawanta. $\mathbf{R}^{*}$

\begin{abstract}
ABSTRAK
Kajian ini bertujuan untuk mengetahui "upaya yang dapat dilakukan untuk mewujudkan pelayanan umum yang lebih responsif yang didasarkan pada hukum yang responsif. Pelayanan umum yang responsif dilaksanakan berdasarkan kebijakan pemerintah di berbagai tingkatan, yang akan diimplementasikan berdasarkan hukum yang responsif yaitu hukum yang digunakan sebagai sarana respons terhadap ketentuan-ketentuan sosial dan aspirasi masyarakat. Demikian pula diperlukan asas-asas pemerintahan yang baik yang dapat menjadi kode etik pemerintahan, karena didalamnya berisi pedoman tingkah laku bagi negara dan aparatnya dalam rangka melayani masyarakatnya. Terwujudkan pelayanan umum yang responsif memerlukan prasayarat adanya birokrasi yang reinvented, dengan kebijakannya yang dilakukan dan yang akan diimplementasikan berdasarkan hukum responsif .

Kata Kunci:Pelayanan Umum yang Responsif, Hukum Responsif.
\end{abstract}

\section{A. PENDAhuluan.}

Di dalam wacana secara teoritis mengenai negara modern, fungsi negara tidak lagi hanya sebagai penjaga malam (watch dog) yang hanya bertindak untuk pengamanan saja jika terjadi suatu serangan. Konsep negara modern menempatkan negara atau Pemerintah untuk

* Dr. L. Tri Setyawanta R, SH.MH adalah Dosen di Fakultas Hukum UNDIP, Allumnus Program Doktor Ilmu Hukum UNPAD Bandung. memegang peran yang lebih aktif, yaitu menyelenggarakan kesejahteraan warganya, sehingga konsep negara tersebut sering disebut sebagai negara kesejahteraan (welfare state).

Negara atau dalam hal ini pemerintahan sebagai welfare state, dalam kegiatannya akan melaksanakan semua hal yang berkaitan dengan upaya mensejahterakan rakyat, baik materiil maupun spirituil. 
Implementasi dari kegiatan negara untuk mensejahterakan rakyatnya tersebut berupa pelayanan kepada masyarakat (public services) dalam berbagai bidang kehidupan.

Untuk mendukung aktivitasnya dalam melaksanakan tugas mensejahterakan rakyatnya, Negara atau Pemerintah membutuhkan adanya suatu sarana yang dapat memberikan legitimasi untuk mengatur warganya. Dalam hal ini hukum akan dapat memberikan legitimasi bagi pelaksanaan kebijakan Pemerintah (public policy) dan sebagai peraturan perundang-undangan telah membuktikan bahwa hukum merupakan suatu alat untuk melaksanakan kebijakan-kebijakan.

\section{B. PERMASALAHAN.}

Dalam era modern seperti sekarang ini, masyarakat memang membutuhkan Pemerintah bukan sebagai penguasa semata, tetapi juga lebih" membutuhkan Pemerintah sebagai birokrasi yang memberikan pelayanan secara lebih baik dan tanggap. Oleh karena itu dalam kajian secara singkat ini akan dibahas terutama mengenai bagaimanakah mewujudkan pelayanan kepada masyarakat yang lebih responsif berdasarkan hukum responsif ?

\section{PEMBAHASAN MASALAH.}

\section{Kebijakan Dan Hukum Responsif.}

Pelayanan umum yang responsif sebagai implementasi dari program pemerintah didasarkan pada kebijakan pemerintah dalam berbagai tingkatnya, yang . dibedakan antara political policy, executive policy, administrative policy dan technical or operational policy ${ }^{64}$. Birokrasi memang diberikan kekuasaan regulasi, yaitu tindakan hukum yang sah untuk mengatur kehidupan masyarakat melalui instrumen yang disebut dengan kebijakan publik (public policy).

Agar kebijakan pemerintah tersebut mendapatkan kekuatan dalam pelaksanaannya, maka kebijakan tersebut memerlukan status formal atau dasar hukum tertentu. Dalam hal ini hukum yang diperlukan adalah hukum responsif yaitu hukum sebagai sarana respon terhadap ketentuan-ketentuan sosial dan aspirasi-aspirasi masyarakat.

Berdasarkan hukum responsif akan dapat dipahami fungsi hukum dalam perspektif emansipasi masyarakat pada hukum. Pespektif tersebut merupakan tinjauan dari bawah terhadap hukum (the bottom"s up view of the law) atau

${ }^{64}$ Bintóro Tjokroamidjojo, Pengantar Administrasi Pembangunan, LP3ES, Jakarta, 1974, hal 115 
dapat juga disebut sebagai perspektif konsumen (the consumer"s perspective of the law). Dengan perspektif ini akan ditinjau kemungkinan - kemungkinan maupun kemampuan-kemampuan hukum sebagai sarana untuk menampung aspirasi masyarakat. ${ }^{65}$.

Dalam hal ini hukum responsif bersifat terbuka terhadap perobahanperobahan masyarakat dan dimaksudkan untuk mengabdi pada usaha meringankan beban kehidupan sosial Demikian pula berupaya mencapai sasaran-sasaran kebijakan sosial seperti keadilan sosial, emansipasi kelompokkelompok sosial yang dikesampingkan dan ditelantarkan, serta perlindungan terhadap lingkungan hidup. Dalam konsep hukum responsif ini menekankan pentingnya makna sasaran kebijakan dan penjabaran yuridis dari reaksi kebijakan serta pentingnya partisipasi kelompok-kelompok dan pribadipribadi yang terlibat dalam penentuan kebijakan ${ }^{66}$. Dengan demikian konsep hukum yang responsif merupakan konsep hukum yang memenuhi tuntutan-tuntutan agar hukum dibuat lebih responsif terhadap kebutuhan sosial yang sangat mendesak dan juga terhadap

\footnotetext{
${ }^{65}$ Ronny Hanitijo Soemitro, Beberapa Perspektif Mengenai Fungsi Hukum Di Dalam Masyarakat, Masalah-Masalah Hukum, N0 10 tahun 1993, FH UNDIP, Semarang, 1993, hal 6e 39 .

66 lbid, hal. 43.
}

masalah keadilan sosial, sambil mempertahankan hasil-hasil konstitusional yang telah dicapai berdasarkan hukum ${ }^{67}$.

Apabila sistem hukum dalam hukum responsif diharapkan akan dapat memberikan wewenang, yang berisi ketegasan tentang maksud dan tujuan kebijakan, maka analisis hukum" harus diarahkan pada polapola kehidupan sosial, lembagalembaga masyarakat dan struktur masyarakat, sehingga tujuan-tujuan hukum dapat tercapai. Demikian pula sumber potensi hukum dan sarana hukum harus dikerahkan untuk mempelajari cara-cara pemecahan terhadap masalah-masalah kemasyarakatan, pengolahan kembali lembaga-lembaga sosial, cara-cara baru dalam melakukan pengawasan, cara-cara baru untuk meningkatkan kejelasan dan pemahaman mengenai keputusan-keputusan hukum, satuansatuan organisasi baru dan pembaharuan struktur kekuasaan. Semua hal tersebut merupakan ciriciri penyembuhan dengan menggunakan sarana hukum responsif ${ }^{68}$.

\footnotetext{
67 A.A.G. Peters dan Koesriani Siswosoebroto, Hukum dan Perkembangan Sosial, Buku Teks Sosiologi Hukum, Pustaka Sinar Harapan, Jakarta, 1990, hal. 158.

68 Philippe Nonet and Philip Selznick, Law and Society in Transsition : Toward Responsive Law, Harper and Row Publisher, New York, Hagerstown, San Fransisco, London, 1978, hal. 73.
} 
2. Asas-Asas Pemerintahan Yang Baik.

Pada dasarnya pelayanan umum yang responsif bertujuan untuk meringankan beban kehidupan sosial, dengan berusaha mencapai sasaran-sasaran kebijakasanaan sosial berdasarkan program-program yang telah dikeluarkan dalam berbagai bidang kehidupan. Implementasi dari kebijakan tersebut diserahkan pada lembaga Pemerintah dalam berbagai bidang dan tingkat yaitu tingkat pusat (nasional) maupun daerah (lokal). Setiap pelaksanaan kebijaksanaan masih membutuhkan pembentukan kebijaksanaan lebih lanjut dalam berbagai bentuk peraturan hukum, apabila kebijaksanaan yang akan diimplementasikan masih harus dinyatakan lebih lanjut.

Dengan demikian dalam rangka pelaksanaan kebijaksanaan, para birokrat akan menentukan sendiri kebijakannya, untuk dapat disesuaikan dengan situasi dimana mereka berada. Demikian pula kebijakan tersebut ditentukan sendiri oleh para birokrat karena keterbatasan sumber daya yang tersedia, baik yang berupa informasi, dana, tenaga ahli, tenaga terampil dan pengetahuan yang mereka miliki ${ }^{69}$.

\footnotetext{
Esmi Warasih, Kegunaan Telaah Kebijakan Publik Terhadap Peranan Hukum Di dalam Masyarakat Dewasa Ini, Masalah-Masalah
}

Dalam hal ini memang harus disadari bahwa implementasi secara esensi, terlihat sebagai masalah teknis atau masalah pengorganisasian, sehingga untuk dapat merespon kebijakan yang efektif perlu adanya tahapan yang harus dilalui, yang berupa perencanaan program dan pelaksanaannya yang menjamin efektifitas program.

Dalam menjalankan aktivitasnya; para birokrat memang mempunyai suatu kebebasan untuk membuat kebijakan tertentu, yang secara yuridis disebut dengan freis ermessen atau discretion. Diskresi ini mempunyai fenomena yang penting dan fundamental dalam rangka implementasi kebijakan $\mathrm{Pe}$ merintah. Dengan demikian pemberian otonomi dan diskresi, yang disertai dengan sumber daya yang memadai merupakan dimensi yang paling strategis didalam melakukan suatu aktivitas. Hal itu disebabakan bahwa hampir semua kebijaksanaan dalam berbagai tingkatannya dibuat oleh para elit pemerintahan.

Disisi lain perlu juga diingat bahwa diskresi (discretionary power) mempunyai kelemahan yang mendasar, yaitu kemungkinan adanya kebijakan yang menyimpang dari peraturan hukum. Oleh karena itu diperlukan adanya asas-asas pemerintahan yang baik yang dapat

Hukum NO II 1994, FH UNDIP, Semarang, 1994, hal 23 
menjadi kode etik pemerintahan, karena didalamnya berisi pedoman tingkah laku bagi negara dan aparatnya dalam rangka melayani masyarakatnya.

Asas-asas pemerintahan yang baik yang terkumpul dalam satu pedoman merupakan kode etik, yang bertujuan untuk menciptakan hubungan kepercayaan antara negara dengan rakyatnya. $\mathrm{Ke}-$ percayaan ini sangat dibutuhkan untuk menggerakkan peran serta masyarakat dalam berbagai program pemerintah. Kepercayaan masyarakat atau rakyat terhadap negara harus ditumbühkan dari sikap profesionalisme aparat pemerintah, baik dalam tindakan hukum maupun tindakan lainnya. Sedangkan sikap profesionalisme dapat ditunjukkan dengan adanya suatu rasionalitas dalam tindakan, kecermatan, keadilan dan kemandirian, Demikian pula kepercayaan dapat tumbuh ketika kebutuhan masyarakat dapat terpenuhi dengan sistem yang telah ada.

Wujud dari asas-asas pemerintahan yang baik tersebut berupa asas kepastian hukum, asas keseimbangan, asas kesamaan, asas bertindak cermat, asas motivasi; asas tidak mencampuradukkan wewenang, dan asas permainan yang layak ${ }^{70}$. Sebagai kode etik,

Kuncoro Purbopranoto, Beberapa Catatan Hukum Tata Pemerintahan daul Peradilan maka asas-asas tersebut tidak hanya bersifat sebagai motivasi, tetapi juga sebagai tujuan dari kegiatan pemerintahan. Sebagai suatu motivasi, kode etik akan memberikan dorongan jiwa dan arah dalam pembentukan keputusan tata usaha negara sebagai suatu kebijakan pemerintah. Sedangkan sebagai suatu tujuan adalah untuk pencapaian kesejahteraan masyarakat.

\section{Penataan Ulang Terhadap Birokrasi Menuly Pelayenan Umum Yang Roeponell.}

Birokrasi merupakan suatu bentuk pengorganisasian yang memiliki berbagai karakteristik tertentu, diantaranya yang menonjol adalah spesialisasi, hirarki, sistem peraturan dan tidak personal " Birokrasi sebagai aparatur pelaksana pemerintahan sering dirasakan masih kurang responsif terhadap aspirasi masyarakat, sehingga pertu dilakukan penataan ulang. Dengan demikian untuk mewujudkan pelayanan umum yang responsif 'terlebih dahulu harus dilakukan reinventing terhadap organisasi birokrasi, sebagaimana yang disyaratkan dalam hukum responsif.

Administrasi Negara, Alumni, Bandung. 1985. 1 hal 47.

Satjipto Rahardjo, Hukum dan Blokrasi, Makalah Dalam Diskusi Panel Dies Natalis Fakultas Hukum UNDIP ke 32. Semarang. 1988, hal 2 . 
Perlunya dilakukan reinventing tersebut dapat disebabkan oleh karakteristik organisasasi yang menjiwainya, yang mempunyai self image bahwa pejabat sangat pintar dan serba tahu, sedangkan masyarakat berada pada posisi sebaliknya. Demikian pula tugas para birokrat bukan melayani masyarakat, tetapi minta dilayani dan pelayanan terhadap masyarakat bukan tugas kewajiban tetapi merupakan hadiah dari birokrasi ${ }^{72}$. Karakteristik tersebut dapat terbentuk karena adanya beberapa sebab yaitu sentralisasi yang amat kuat, menilai tinggi keseragaman dalam struktur birokrasi, pendelegasian wewenang yang kabur dan kesulitas menyusun uraian tugas dan analisis jabatan. Dalam kenyataannnya sebab-sebab tersebut merupakan sebagian ciri-ciri umum dari model organisasi birokrasi yang legal rasional.

Dengan demikian dalam pelayanan umum yang responsif mensyaratkan adanya perobahan tindakan yang harus dilakukan pemerintah yang berupa :

a. Listen to people's concerns and involve them in decision about

\footnotetext{
12 Benny K. Harman, Konfigurasi Politik dan Kekuasaan Kehakiman, Elsam, Jakarta, 1997, hal 36.

The Prime Minister and the Minister of the Cabinet Office, Responsive Public Services, in Moderning Government, London, Maret, 1999.
} hal 25. how services should be provided.

b. Are sensitive to the needs of particular groups of people or businesses.

c. Reflect people's real lives. Government should be organised so that people don't have to hunt down services by a process of trial and error.

d. Make it easy to complain and get a result when things go wrong .

Terwujudnya pelayanan umum yang responsif memang memerlukan prasyarat adanya pemerintahan yang baik (good governance) yang telah ditata ulang, sehingga diharapkan muncul pemerintahan yang bersih, berwibawa, ekonomis, netral, mampu, efektif dan efisien. Menurut David Obsborne dalam bukunya "Reinventing Govemment, pemerintah atau birokrasi yang reinventing dan siap dalam era global harus melakukan prinsip-prinsip yaitu pomerintah yang katalistik, memberdayakan masyarakat, berorientasi pada perluasan pelayanan masyarakat, didorong oleh misi. kompetitif, antisipatif dan berorientasi pada pasar.

Pemerintah yang katalistik akan menempatkan pemerintah sebagai mediator dan sebagai pemikul beban, sehingga fungsi utamanya adalah untuk mengarahkan masyarakat. Sebagai pemberi arah, maka 
setiap komponen pemerintah harus memiliki dasar pengetahuan dan ketrampilan yang dapat diandalkan. Hal itu diperlukan untuk dapat menampung aspirasi-aspirasi yang berkembang didalam masyarakat, dalam rangka mewujudkan pelayanan umum yang. responsif yang tanggap akan kebutuhan masyarakat, tetapi bukan diadakan sebagai sarana untuk melayani penghidupan mereka $^{74}$.

Pemerintah yang memberdayakan masyarakat, akan menjelaskan bagaimana menumbuhkan perasaan bahwa pemerintah menupakan milik masyarakat dan masyarakat dapat merasakan memiliki pemerintahnya, karena adanya kemampuan dari pemerintah untuk memberdayakan masyarakatnya melalui peningkatan partisipasinya. Dengan demikian dapat dikatakan bahwa pemerintah yang berhasil dalam melaksanakan tugasnya, merupakan pemerintahan yang diharapkan dan dikehendaki oleh masyarakat dalam era sekarang ini. Dalam hal ini pemerintah tidak harus mengurusi penyediaan fasilitas kesehatan, pendidikan, perumahan, transportasi dan lainnya, tetapi mengupayakan agar masyarakat memiliki pemberdayaan untuk menjangkau apa yang mereka butuhkan ${ }^{75}$

\footnotetext{
74 Ibid, hal 23

Bay Suryawikarta, Paradigma Reinventing Government, Makalah pada pembekalan Peningkatan Kinerja Pembantu Bupati/Walikota,
}

Berdasarkan pelayanan umum yang responsif, misalnya yang telah dilakukan di Inggris, di bidang kesehatan akan dapat membuat masyarakat aktif berpartisipasi dengan melakukan konsultasi setiap saat mengenai kesehatannya. Dibidang tenaga kerja, masyarakat akan "mampu mencari dan melamar pekerjaan melalui employment service dengan menggunakan telepon dan internet. Dibidang pendidikan, para pelajar dari semua usia akan mampu mengakses materi-materi yang berkualitas melalui jaringan internet $^{76}$. Hal-hal tersebut merupakan contoh-contoh pemberdayaan masyarakat oleh Pemerintah yang reinvented dalam wujudnya sebagai pelayanan umum yang responsif.

Birokrasi atau pemerintah yang dapat mewujudkan pelayanan umum yang responsif, juga harus berorientasi pada perluasan pelayanan masyarakat. Dalam hal ini Pemerintah harus secara aktif meluncurkan program-program baru untuk meningkatkan peran serta masyarakat umum dan dunia usaha di bidang pelayanan umum. Program-program tersebut berfokus nasional, warga negara, Departemen atau perwakilan Pemerintah yang dikelola secara terpusat, berfokus

Kerjasama Dirjen POUD dan FISIP UNPAD Bandung, 1999, hal . 2.

The Prime Minister and the Minister of the Cabinet Office.Op.Cit, Hal 3. 
pada golongan dan program yang berbasis wilayah.

Demikian pula birokrasi yang dapat mewujudkan pelayanan umum yang responsif harus didorong oleh misi untuk mewujudkan kesejahteraan kehidupan masyarakatnya secara luas. Dengan demikian Pemerintah tidak hanya memberikan pelayanan dan program yang efektif dan efisien, tetapi juga harus menjalin kerjasama dengan semua pihak yang bersifat responsif.

Pelayanan umum yang responsif juga dapat diwujudkan oleh pemerintah yang bersifat antisipatif, dengan memikirkan adanya tindak lanjut atau tindakan dimasa mendatang (furute action). Hal ini sangat penting untuk mencegah timbulnya ekses-ekses yang tidak diinginkan dalam rangka pelaksanaan pelayanan umum. Demikian juga dimaksudkan untuk menampung dinamika yang berkembang ditengah-tengah masyarakat, agar selalu dapat dijangkau oleh birokrasi pemerintah.

Terwujudnya pelayanan umum yang responsif juga harus ditunjang oleh pemerintah yang berorientasi pada pasar, sehingga dapat memberikan pelayanan yang mencerminkan kebutuhan-kebutuhan bagi dunia usaha dan akses untuk usaha. Hal itu disebabkan dunia usaha memang memegang peranan yang penting dan menentukan untuk menjalankan roda perekonomian dan perdagangan nasional.

\section{KESIMPULAN.}

Pelayanan umum yang responsif dilaksanakan berdasarkan kebijakan pemerintah di berbagai tingkatan, yang akan diimplementasikan berdasarkan hukum yang responsif yaitu hukum yang digunakan sebagai sarana respons terhadap ketentuanketentuan sosial dan aspirasi masyarakat. Hukum responsif bersifat terbuka terhadap perobahan masyarakat dan bertujuan untuk mengabdi pada upaya meringankan beban kehidupan sosial dan mencapai sasaran-sasaran kebijakan sosial. Terwujudkan pelayanan umum yang responsif memerlukan prasyarat adanya birokrasi yang reinvented, dengan kebijakannya yang dilakukan dan yang akan diimplementasikan berdasarkan hukum responsif . 


\section{DAFTAR PUSTAKA}

Benny K. Harman,

Konfigurasi

Politik dan

Kekuasaan

Kehakiman,Elsam, Jakarta, 1997.

Bintoro Tjokroamidjojo, Pengantar Administrasi Pembangunan, LP3ES, Jakarta, 1974.

Bay Suryawikarta, Paradigma Reinventing Government, Makalah pada pembekalan Peningkatan Kinerja Pembantu Bupati/Walikota, Kerjasama Dirjen POUD dan FISIP UNPAD, Bandung, 1999.

Esmi Warasih, Kegunaan Telaah Kebijakan Publik Terhadap Peranan Hukum Di dalam Masyarakat Dewasa Ini, Masalah-Masalah Hukum NO II 1994, FH UNDIP, Semarang, 1994

Kuncoro Purbopranoto, Beberapa Catatan Hukum Tata Pemerintahan dan Peradilan Administrasi Negara, Alumni, Bandung, 1985.

Nonet, Philippe and Selznik, Philip, Law and Society in Transition :Toward Responsive Law, Harper and Row Publisher, New York, San Fransisco, London, 1978.

Ronny Hanitijo Soemitro, Beberapa Perspektif Mengenai Fungsi Hukum Di Dalam Masyarakat, Masalah-Masalah Hukum, NO 10 tahun 1993, FH UNDIP, Semarang, 1993

Satjipto Rahardjo, Hukum dan Birokrasi, Makalah Dalam Diskusi Panel Dies Natalis
Fakultas Hukum UNDIP ke 32 , Semarang, 1988

The Prime Minister and the Minister of the Cabinet Office, Responsive Public Services, in Moderning Government, London, Maret, 1999. 